\title{
An empirical study on market timing theory: A case study of Tehran Stock Exchange
}

\author{
Hadi Nasiri $^{\mathrm{a}^{*}}$ and Seyed Yousef Ahadi Serkani ${ }^{\mathrm{b}}$
}

${ }^{a}$ M.A. Student, Department of Accounting, School of Management,Tehran North Branch, Islamic Azad University (IAU), Tehran, Iran ${ }^{b}$ Assist.Prof. \& Faculty Member, Department of Accounting, Firoozkooh Branch, Islamic Azad University (IAU), Iran

\begin{tabular}{|c|c|}
\hline ARTICLEINFO & A B S T R A C T \\
\hline $\begin{array}{l}\text { Article history: } \\
\text { Received July 16, } 2012 \\
\text { Received in Revised form } \\
\text { August, 27, 2012 } \\
\text { Accepted 20 September } 2012 \\
\text { Available online } \\
\text { September } 272012 \\
\text { Keywords: } \\
\text { Market timing theory } \\
\text { TSE } \\
\text { Book value } \\
\text { Financing }\end{array}$ & $\begin{array}{l}\text { One of the most important issues in financing corporate is to find appropriate method to make a } \\
\text { wise selection between getting loans and increasing the number of shares. There are different } \\
\text { theories for making appropriate financing methods. The primary purpose of this paper is to } \\
\text { investigate this issue based on market timing theory. The proposed model of this paper chooses } \\
\text { selective companies from Tehran Stock Exchange. The proposed model of this paper uses } \\
\text { regression analysis on two different models. The primary purpose of the first model given in } \\
\text { this paper is to study the effect of market timing theory. In this part of survey, we measure the } \\
\text { effect of the ratio of market value to book value on the sources of financing firms though } \\
\text { increase in equities. Based on the results, we can conclude that as the ratio of market value to } \\
\text { book value increases, firms tend to increase their equity though an increase to the number of } \\
\text { shares. The first hypothesis of this paper is confirmed. The second model is associated with the } \\
\text { relationship with mean ratio of market value on weighted book value and Leverage and the } \\
\text { results of this paper do not confirm such relationship. }\end{array}$ \\
\hline
\end{tabular}

(c) 2012 Growing Science Ltd. All rights reserved.

\section{Introduction}

Financing plays essential role on increasing company's capabilities to develop their business. There are literally two primary sources of financing a particular firm, increasing the number of shares and absorbing loans. Of course, a combination of these two methods is also possible but the primary question arises when we look for the best methods. During the past few years, there have been many studies to study different issues.

Elliott et al. (2007) used an earnings-based fundamental valuation technique to examine the effect of market timing on the firm's policy of funding the financing deficit. They criticized that their valuation metric could provide a superior measure of equity misevaluation compared with traditional model.

\footnotetext{
* Corresponding author. Tel: +989128414526

E-mail addresses: h.nasiri1986@gmail.com (H. Nasiri) 
The study also eliminated the need to infer market timing based on the actions of corporate insiders or other indirect measures and reported a relatively strong positive relationship between the degree in which a firm was overvalued and the proportion of the firm's financing deficit, which was funded with equity. They also reported that overvaluation in the 1990s led to equity being increasingly popular over debt.

Elliott et al. (2008), in other study, examined the market timing theory of capital structure based on earnings-based valuation technique, which allows to separate equity mispricing from growth options and time-varying adverse selection. This could also help us prevent the multiple interpretations of book-to-market ratio. They reported that equity market mispricing played a substantial role in the security choice decision.

Mahajan and Tartaroglu (2008) studied the equity market timing hypothesis of capital structure in major industrialized (G-7) countries and reported that leverage of firms was negatively associated with the historical market-to-book ratio in those countries, but this negative relationship did not seem to be attributed to equity market timing. They also reported that there was no association between equity issues and market-to-book ratios at the time of equity financing decisions by Japanese corporation.

Antoniou et al. (2009) investigated whether firms in the UK market make full implementation of debt issuances for hedging purposes or whether they had other considerations. They reported that firms' choices of debt issues were primarily driven by debt market conditions in an attempt to lower their expenditures of capital rather than managing their firm-specific interest rate exposures.

Butler et al. (2011) used a cross-sectional technique and reported that the amount of net financing was more important than its composition in explaining future stock returns. They also reported that measures of real investment were correlated with future returns and measures of managerial market timing were not. Hu et al. (2011) performed another empirical analysis on the relationship between initial public offering waves and market timing on the basis of product market competition in China. They investigated the optimal timing of going public after comparing the advantage of going public and issuing cost.

Jasemi et al. (2011) presented a model to do stock market timing based on a supervised feed-forward neural network and the technical analysis of Japanese Candlestick. The network was not trained based on the candlestick lines alone or in combination.

\section{The proposed model}

The proposed study of this paper considers the following three hypotheses,

1. When the ratio of market cap on book value increases, firms prefer to do financing through increasing the number of shares.

2. There is a positive relationship between financing of firms and Tehran Stock Exchange index.

3. There is a reverse relationship between Leverage and mean weighted ratio of market cap on book value proportion to increase on the number of shares.

The proposed study of this paper gathers the financial information of all listed firms traded in Tehran Stock Exchange over the period of 2007-2011. The proposed study only focused on listed companies whose fiscal years started from March to May of each year. The other criterion associated with the proposed study of this paper is that shares of the selected firms must have been active during period of study and there must be no change in their fiscal calendar. The study did not include the shares of 
holdings, banks, insurance firms. Finally, the information of the firms must be available for course of study. There are nine variables associated with the proposed model of this paper including ratio of market cap on book value, market performance, weighted mean of market value to book value adjusted based on net equity, net increase in equity, Leverage ratio, profitability, interest rate, capability of mortgaging assets and firm size. We first present details of computations of these formulas,

2.1. Net increase in equity $\left(\frac{e}{A}\right)_{i, t}$

In this survey, the ratio is calculated as follows,

$\left(\frac{e}{A}\right)_{i, t}=\frac{\Delta B E_{i, t}-\Delta R E_{i, t}}{T A_{i, t}}$

where $\left(\frac{e}{A}\right)_{i, t}$ is the net increase of firm $i$ in year $t, \Delta B E_{i, t}$ is the change in book value of total equities of firm $i$ between year $t-1$ and $t, \Delta R E_{i, t}$ is the change in accumulated profit of firm $i$ between year $t-1$ and $t$ and $T A_{i, t}$ is the net value of total assets of firm $i$ between year $t-1$ and $t$.

\subsection{Leverage ratio Leverage $_{i, t}$}

Leverage ratio is calculated as Leverage $e_{i, t}=\frac{T D_{i, t}}{T A_{i, t}}$ where $T D_{i, t}$ is total debts of firm $i$ in year $t$ and $T A_{i, t}$ is the total book value of all assets of firm $i$ in year $t$.

\subsection{Market value on book value $\left(M_{T, t}\right)$}

In this research, the ratio of market value on book value is calculated from divding book value of equity by market value at the end of each fiscal year.

\subsection{Market performance ( MARKET $_{i, t}$ )}

Market performance is calculated by measuring the growth on the market index.

\subsection{Mean ratio of market value on weighted book value $\left(M_{\text {ewa }, \text { it }}\right)$}

This ratio is calculated as follows,

$$
\mathrm{MTB}_{\text {ewa }, i t}=\sum_{s=0}^{t} \frac{e_{i s}}{\sum_{r=0}^{t} e_{i r}} * M T B_{i s}
$$

where $e_{i s}$ is the increase in equaity of firm $i$ in year $s, e_{i r}$ is the increase in equaity of firm $i$ in year $r$, $M T B_{i s}$ is the ratio of market value to book value of firm $i$ in year $s$, and finally $r$ and $s$ are the number years of study up to year $t$.

\subsection{Profitability $\left(P R O F_{i, t}\right)$}

Profitability in this research is defined as follows 
$\mathrm{PROF}_{i, t}=\frac{\mathrm{EBIT}_{i, t}}{T A_{i, t}}$

where $E B I T_{i, t}$ is earning before interst and tax of firm $i$ in year $t, T A i, t$ is total assets of firm $i$ at the end of year $t$.

\subsection{Interest rate ( $\left.I N T E R E S T_{i, t}\right)$}

In this survey, we consider the average rate of interest announced by different banks.

\subsection{Capability of assets for mortgage $\left(T A N G_{i, t}\right)$}

Fixed assets represent the capability of receiving loans from banks or any other financial firms by mortgaging them and an increase in total fixed assets could help reduce the risk of mortgaging the assets and the ratio is calculated as follows,

$T A N G_{i, t}=\frac{P P E_{i, t}+\text { Invent }_{i, t}}{T A_{i, t}}$,

where PPEi,t is the net value of fixed assets including all equipments of firm $i$ at the end of year $t$, Invent $_{i, t}$ is the net inventory of firm $i$ at the end of year $t, T A_{i, t}$ is book value of all assets of firm $i$ at the end of year $t$.

\subsection{Size of firm $\left(\operatorname{SIZE}_{i, t}\right)$}

In this paper, we use natural logarithm of net revenue at the end of each period as follows,

$$
\operatorname{SIZE} E_{i, t}=\operatorname{LN}\left(S_{i, t}\right)
$$

where $S_{i, t}$ is the net revenue of firm $i$ at the end of year $t$.

\section{The proposed model}

The proposed model of this paper uses the following two models

$$
\left(\frac{e}{A}\right)_{i, t}=\alpha_{i, t}+\beta_{1} M_{i, t}+\beta_{2} M_{A R K E T}+\beta_{3} P_{R O F}+\beta_{i, t} \operatorname{INTESET~}_{i, t}+\varepsilon_{i, t} \text {, }
$$

Leverage $_{i, t}=\alpha_{i, t}+\beta_{1}$ MTB $_{\text {ewa }, i t}+\beta_{2}$ MARKET $_{i, t}+\beta_{3}$ TANG $_{i, t}+\beta_{4}$ PROF $_{i, t}+\beta_{5} \operatorname{SIZE}_{i, t}+\varepsilon_{i, t}$.

We first present details of the data used for the proposed study of this paper. Table 1 shows details of some statistical observations including the number of observations $(\mathrm{N})$, mean, standard deviation, min and max, skewness and string.

Table 1

Statistical observations of the input data

\begin{tabular}{llllllll}
\hline & $\mathrm{N}$ & Mean & Std. dev. & min & max & Skewness & String \\
\hline$(e / A)_{i, t}$ & 1040 & 0.0166 & 0.0673 & -0.999 & 0.413 & -3.400 & 66.026 \\
Leverage & 1040 & 0.6483 & 0.2222 & 0.096 & 2.356 & 1.386 & 8.198 \\
MTB $_{i, t}$ & 1036 & 1.693 & 3.004 & -53.9 & 19.004 & -8.402 & 142.4 \\
MARKET $_{i, t}$ & 1040 & 0.3344 & 0.3569 & -0.132 & 0.858 & 0.245 & -1.377 \\
MTB $_{\text {ewa }, i t}$ & 1039 & 1.408 & 1.549 & -5.520 & 12.943 & 1.472 & 7.763 \\
PROF $_{i, t}$ & 1040 & 0.158 & 0.127 & -0.561 & 0.769 & 0.689 & 3.089 \\
INTEREST $_{i, t}$ & 1040 & 0.152 & 0.275 & 0.000 & 5.210 & 11.63 & 166.4 \\
TANG $_{\text {SIZE }}$ & 1040 & 0.480 & 0.192 & 0.004 & 0.945 & -0.062 & -0.421 \\
\hline
\end{tabular}


Based on the results of Table 1, we realize that we can perform the regression analysis on both models using panel data. Table 2 shows some of the statistical observations required to validate the results.

Table 2

The summary of statistical observations for the first model

\begin{tabular}{lllllll}
\hline Jarque-Bera & \multicolumn{4}{l}{ Breusch-Pagan } & Durbin-Watson & Ramsy \\
\hline$\chi^{2}$ & P-value & $F$ & $P$-value & $\mathrm{D}$ & $F$ & $P$-value \\
\hline 3.228 & 0.1989 & 2.701 & 0.0294 & 2.30 & 3.736 & 0.0535 \\
\hline
\end{tabular}

The results of regression technique is as follows,

$\left(\frac{e}{A}\right)_{i, t}=0.0161+0.0006 \mathrm{MTB}_{i, t}+0.0018 \mathrm{MARKET}_{i, t}+0.0044 \mathrm{PROF} \mathrm{F}_{i, t}-0.0040 \operatorname{INTESET}_{i, t}+\varepsilon_{i, t}$

t-student (33.839) (4.188)

(5.060)

P-value (0.0000) (0.000)

$(0.000)$

(0.0185) F-value $=2.324$ P-value $=0.00 \mathrm{C}$

As we can observe from the results of regression technique given in Eq. (3), all coefficients are meaningful when the level of significance is five percent. The coefficients of the first three variables are positive, which is in accordance with what we expect and the coefficient of the last independent variable, Interest, is negative, which is, again, in accordance with what we expected. The primary purpose of the first model given in this paper is to study the effect of market timing theory. In this part of survey, we measure the effect of the ratio of market value to book value on the sources of financing firms though increase in equities. Based on the results, we can conclude that as the ratio of market value to book value increases, firms tend to increase their equity though an increase to the number of shares. The first hypothesis of this paper is confirmed. The second hypothesis is, again, associated with market timing theory and we look to see the effect of an increase on market on financing firms through increase in the number of shares.

The other hypothesis of this paper is associated with the relationship between Leverage and mean of the ratio of market value on weighted book value proportion to equity. Table 3 shows necessary statistical observation obtained for the second model stated in Eq. (2).

Table 3

The summary of statistical observations for the second model

\begin{tabular}{lllllll}
\hline Jarque-Bera & & \multicolumn{2}{l}{ Breusch-Pagan } & Durbin-Watson & \multicolumn{2}{l}{ Ramsy } \\
\hline$\chi^{2}$ & P-value & $F$ & $P$-value & D & $F$ & $P$-value \\
\hline 2.526 & 0.4083 & 4.559 & 0.0004 & 2.26 & 0.838 & 0.3602 \\
\hline
\end{tabular}

The results of regression technique is as follows,

$\begin{array}{lccccc}\text { Leverage }_{i, t}= & 0.7335-0.0003 M T B_{\text {ewa }, i t} & +0.0065 M A R K E T_{i, t} & -0.0372 \text { TANG }_{i, t} & -0.5500 P R O F_{i, t} & \\ \text { t-student } & (9.555)(-0.2442) & (2.239) & (-2.105) & (-20.474) & (0.1966) \\ \text { P-value } & (0.0000)(0.8071) & (0.0255) & (0.0357) & (0.0000) & (0.8441)\end{array}$

F-value $=128.84, \mathrm{P}$-value $=0.000$

As we can observe from the results, t-student value associated with $M T B_{\text {ewa,it }}$ is not statistically meaningful and we cannot reject the null hypothesis. Therefore, there is no meaningful relationship between this variable and Leveraging the firm. 


\section{Conclusion}

In this paper, we have presented an empirical study on selected firms listed on Tehran Stock Exchange. The proposed study of this paper studied whether there is any relationship between financing firm and other issues. The proposed model of this paper has selected companies from Tehran Stock Exchange based on four major criteria and examined different hypotheses using regression analysis based on two different models. The primary purpose of the first model given in this paper was to study the effect of market timing theory. In this part of survey, we measured the effect of the ratio of market value to book value on the sources of financing firms though increase in equities. Based on the results, we have concluded that as the ratio of market value to book value increases, firms tend to increase their equity though an increase to the number of shares. However, the results of this survey did not find any evidence to believe there was any relationship between the ratio of market value on weighted book value and Leverage.

\section{Acknowledgment}

The authors would like to thank the anonymous referees for their comments on earlier version of this paper.

\section{References}

Antoniou, A., Zhao, H., \& Zhou, B. (2009). Corporate debt issues and interest rate risk management: Hedging or market timing? Journal of Financial Markets, 12(3), 500-520.

Butler, A.W., Cornaggia, J., Grullon, G., \& Weston, J.P. (2011). Corporate financing decisions, managerial market timing, and real investment. Journal of Financial Economics, 101(3), 666-683.

Elliott, W.B., Koëter-Kant, J., \& Warr, R.S. (2007). A valuation-based test of market timing. Journal of Corporate Finance, 13(1), 112-128.

Elliott, W.B., Koëter-Kant, J., \& Warr, R.S. (2008). Market timing and the debt-equity choice. Journal of Financial Intermediation, 17(2), 175-197.

Hu, Z., Han, L., \& Guo, X. (2011). An empirical analysis on the relationship between IPO waves and market timing on the basis of product market competition in China. Procedia Environmental Sciences, 11(A), 218-226.

Jasemi, M., Kimiagari, A.M., \& Memariani, A. (2011). A modern neural network model to do stock market timing on the basis of the ancient investment technique of Japanese Candlestick. Expert Systems with Applications, 38(4), 3884-3890.

Mahajan, A., \& Tartaroglu, S. (2008). Equity market timing and capital structure: International evidence. Journal of Banking \& Finance, 32(5), 754-766. 